\title{
Front Matter: Volume 10172
}

, "Front Matter: Volume 10172," Proc. SPIE 10172, A Tribute Conference Honoring Daniel Inman, 1017201 (26 April 2017); doi: 10.1117/12.2279846

Event: SPIE Smart Structures and Materials + Nondestructive Evaluation and SPIE. Health Monitoring, 2017, Portland, Oregon, United States 


\title{
PROCEEDINGS OF SPIE
}

\section{A Tribute Conference Honoring Daniel Inman}

\author{
Donald J. Leo \\ Pablo A. Tarazaga \\ Editors
}

29 March 2017

Portland, Oregon, United States

Sponsored by

SPIE

Co-sponsored by

OZ Optics, Ltd. (United States)

Polytec, Inc. (United States)

Fiberguide Industries (United States)

Frontiers Media (Switzerland)

Cooperating Organization

Jet Propulsion Laboratory (United States)

Published by

SPIE 
The papers in this volume were part of the technical conference cited on the cover and title page. Papers were selected and subject to review by the editors and conference program committee. Some conference presentations may not be available for publication. Additional papers and presentation recordings may be available online in the SPIE Digital Library at SPIEDigitallibrary.org.

The papers reflect the work and thoughts of the authors and are published herein as submitted. The publisher is not responsible for the validity of the information or for any outcomes resulting from reliance thereon.

Please use the following format to cite material from these proceedings:

Author(s), "Title of Paper," in A Tribute Conference Honoring Daniel Inman, edited by Donald J. Leo, Pablo A. Tarazaga, Proceedings of SPIE Vol. 10172 (SPIE, Bellingham, WA, 2017) Seven-digit Article CID Number.

ISSN: 0277-786X

ISSN: 1996-756X (electronic)

ISBN: 9781510608290

ISBN: 9781510608306 (electronic)

Published by

SPIE

P.O. Box 10, Bellingham, Washington 98227-0010 USA

Telephone +1 3606763290 (Pacific Time) · Fax +1 3606471445

SPIE.org

Copyright (c) 2017, Society of Photo-Optical Instrumentation Engineers.

Copying of material in this book for internal or personal use, or for the internal or personal use of specific clients, beyond the fair use provisions granted by the U.S. Copyright Law is authorized by SPIE subject to payment of copying fees. The Transactional Reporting Service base fee for this volume is $\$ 18.00$ per article (or portion thereof), which should be paid directly to the Copyright Clearance Center (CCC), 222 Rosewood Drive, Danvers, MA 01923. Payment may also be made electronically through CCC Online at copyright.com. Other copying for republication, resale, advertising or promotion, or any form of systematic or multiple reproduction of any material in this book is prohibited except with permission in writing from the publisher. The CCC fee code is 0277-786X/17/\$18.00.

Printed in the United States of America.

Publication of record for individual papers is online in the SPIE Digital Library.

\section{SPIE. DIGITAL \\ SPIEDigitalLibrary.org}

Paper Numbering: Proceedings of SPIE follow an e-First publication model. A unique citation identifier (CID) number is assigned to each article at the time of publication. Utilization of CIDs allows articles to be fully citable as soon as they are published online, and connects the same identifier to all online and print versions of the publication. SPIE uses a seven-digit CID article numbering system structured as follows:

- The first five digits correspond to the SPIE volume number.

- The last two digits indicate publication order within the volume using a Base 36 numbering system employing both numerals and letters. These two-number sets start with 00, 01, 02, 03, 04, 05, 06, 07, 08, 09, OA, OB ... OZ, followed by 10-1Z, 20-2Z, etc. The CID Number appears on each page of the manuscript. 


\title{
Contents
}

\author{
$\checkmark$ Authors \\ vii Conference Committee
}

\section{A TRIBUTE CONFERENCE HONORING DANIEL INMAN}

1017203 Some recently obtained results in classical vibration and acoustics: coexistence of traveling and standing waves in a one-dimensional non-dispersive continuum (Invited Paper) [10172-1]

1017204 Fractional order absolute vibration suppression (AVS) controllers [10172-2]

1017205 Multifunctional smart composites with integrated carbon nanotube yarn and sheet [10172-3]

1017206 Electromechanical impedance-based fault detection in a rotating machine by using an operating condition compensation approach [10172-4]

10172 OB Integrated fiber optic structural health sensors for inflatable space habitats [10172-9]

10172 OE Recent developments on SMA actuators: predicting the actuation fatigue life for variable loading schemes [10172-12]

10172 OF Gust prediction via artificial hair sensor array and neural network [10172-13]

$101720 \mathrm{~A}$ A new hybrid piezo-actuated compliant mechanism with self-tuned flexure arm [10172-14]

$10172 \mathrm{Ol}$ Analytical and finite element performance evaluation of embedded piezoelectric sensors in polyethylene [10172-16]

$101720 \mathrm{~J}$ On the decentralized observer/controller strategy for disturbance rejection [10172-17]

10172 OK Simultaneous passive broadband vibration suppression and energy harvesting with multifunctional metastructures [10172-18]

$10172 \mathrm{OL}$ Piezoelectric interfaces enabled energy harvesting and tailored damping in fiber composites [10172-19] 
Proc. of SPIE Vol. 10172 1017201-4 Downloaded From: https://www.spiedigitallibrary.org/conference-proceedings-of-spie on 26 Apr 2023
Terms of Use: https://www.spiedigitallibrary.org/terms-of-use 


\title{
Authors
}

Numbers in the index correspond to the last two digits of the seven-digit citation identifier (CID) article numbering system used in Proceedings of SPIE. The first five digits reflect the volume number. Base 36 numbering is employed for the last two digits and indicates the order of articles within the volume. Numbers start with 00, 01, 02, 03, 04, 05, 06, 07, 08, 09, 0A, 0B...0Z, followed by 10-1Z, 20-2Z, etc.

\author{
Anton, Steven R., 01 \\ Beblo, Richard V., OF \\ Bergman, Lawrence A., 03 \\ Blanchard, Antoine, 03 \\ Bowland, Christopher C., OL \\ Cahay, Marc, 05 \\ Cao, Junyi, OG \\ Castellucci, Matthew A., OB \\ Cavalini, A. A., Jr., 06 \\ Chaudhary, Sumeet, 05 \\ Chauhan, Devika, 05 \\ Dong, ZhongZhe, 0J \\ Faria, Cassio T., OJ \\ Finzi Neto, R. M., 06 \\ Garg, Naman, OB \\ Guimarães, C. G., 06 \\ Halevi, Yoram, 04 \\ Hobeck, Jared D., OK \\ Hou, Guangfeng, 05 \\ Hwang, Hyun-Sik, OL \\ Inman, Daniel J., OK \\ Lagoudas, Dimitris C., OE \\ Lalley, Nicholas, 05 \\ Ling, Mingxiang, $0 G$ \\ Liu, Yijun, 05 \\ Malakooti, Mohammad H., OL \\ Mast, David, 05 \\ McFarland, D. Michael, 03 \\ Moinuddin, Khwaja, 05 \\ $\mathrm{Ng}$, Vianessa, 05 \\ Ohanian, Osgar John, III, OB \\ Paine, Michael, 05 \\ Pankonien, Alexander M., OF \\ Patterson, Brendan A., OL \\ Rabelo, D. S., 06 \\ Rabiee, Massoud, 05 \\ Reich, Gregory W., OF \\ Safaei, Mohsen, 0 I \\ Schulz, Mark, 05 \\ Shanov, Vesselin, 05 \\ Sodano, Henry A., OL \\ Song, Yi, 05 \\ Steffen, V., Jr., 06 \\ Thapa Magar, Kaman S., OF \\ Tsuruta, K. M., 06 \\ Vakakis, Alexander F., 03 \\ Wheeler, Robert W., OE
}

Xiao, Yongxiong, 03

Yin, Zhangzhang, 05

Zhang, Xueji, OJ 
Proc. of SPIE Vol. 10172 1017201-6

Downloaded From: https://www.spiedigitallibrary.org/conference-proceedings-of-spie on 26 Apr 2023 Terms of Use: https://www.spiedigitallibrary.org/terms-of-use 


\title{
Conference Committee
}

\author{
Symposium Chairs
}

Jayanth N. Kudva, NextGen Aeronautics, Inc. (United States)

Theodoros E. Matikas, University of loannina (Greece)

Symposium Co-chairs

Tribikram Kundu, The University of Arizona (United States)

Gregory W. Reich, Air Force Research Laboratory (United States)

Conference Chairs

Donald J. Leo, The University of Georgia (United States)

Pablo A. Tarazaga, Virginia Polytechnic Institute and State University

(United States)

Session Chairs

Tuesday Plenary Session

Jayanth N. Kudva, NextGen Aeronautics, Inc. (United States)

Session 1

Donald J. Leo, The University of Georgia (United States)

Session 2

Ya S. Wang, Stony Brook University (United States)

Session 3

Steven Anton, Tennessee Technological University (United States)

Session 4

Henry A. Sodano, University of Michigan (United States)

Session 5

Pablo A. Tarazaga, Virginia Polytechnic Institute and State University (United States) 
Proc. of SPIE Vol. 10172 1017201-8

Downloaded From: https://www.spiedigitallibrary.org/conference-proceedings-of-spie on 26 Apr 2023 Terms of Use: https://www.spiedigitallibrary.org/terms-of-use 